\title{
Social Grant Payments - a Crisis Averted?
}

\section{Kitty Malherbe}

\section{(2) OpenEdition}

\section{Journals}

Electronic version

URL: https://journals.openedition.org/rdctss/2479

DOI: $10.4000 /$ rdctss. 2479

ISSN: 2262-9815

\section{Publisher}

Centre de droit comparé du travail et de la sécurité sociale

\section{Printed version}

Date of publication: 1 December 2017

Number of pages: 224-227

ISSN: $2117-4350$

\section{Electronic reference}

Kitty Malherbe, "Social Grant Payments - a Crisis Averted?", Revue de droit comparé du travail et de la sécurité sociale [Online], 4 | 2017, Online since 01 November 2021, connection on 04 December 2021. URL: http://journals.openedition.org/rdctss/2479 ; DOI: https://doi.org/10.4000/rdctss.2479

\section{(c) (i) (9)}

Revue de droit comparé du travail et de la sécurité sociale est mise à disposition selon les termes de la Licence Creative Commons Attribution - Pas d'Utilisation Commerciale - Pas de Modification 4.0 International. 


\title{
KITTY MALHERBE
}

\author{
University of the Western Cape
}

\section{Social Grant Payments - a Crisis Averted?}

\section{I - SOCIAL ASSISTANCE IN SOUTH AFRICA}

Section 27(1)(c) of the South African Constitution guarantees everyone the right of access to social security, including appropriate social assistance for those who are unable to support themselves and their dependants. The state is required to take reasonable measures within available resources to achieve the progressive realisation of the right of access to social security. The number of social grant beneficiaries has risen to 17.4 million in 2017, which translates to just under $30 \%$ of South Africans. ${ }^{1}$ The range and scale of the social grants system is unique in the developing world ${ }^{2}$ and the grants have been credited with reducing poverty and inequality and in mitigating the consequences of high levels of unemployment. ${ }^{3}$

The South African Social Security Agency (SASSA) was created in terms of the South African Social Security Agency Act 9 of 2004 (the SASSA Act) as the sole national agency to administer applications for and payment of grants to beneficiaries who qualified for social assistance (in terms of the Social Assistance Act 13 of 2004). SASSA replaced the previous fragmented system where each of the nine provinces was responsible for administering and paying grants in that province. There was great hope that SASSA would be an improvement on the fragmentation and maladministration that characterised the previous system, and for a period of time SASSA delivered on the promise of improved administration of social assistance.

\section{II - HOW THE CRISIS UNFOLDED}

Section 4 of the SASSA Act enables SASSA, with the concurrence of the Minister of Social Development, to enter into agreements with other parties to ensure effective payments of grants to beneficiaries. SASSA initially contracted with various service providers. However, this changed in 2012 when SASSA concluded a contract with Cash Paymaster Services (Pty) Ltd (CPS) for the payment of grants nationally for five years. In 2013 the Constitutional Court declared the award of the tender to CPS to be constitutionally invalid ${ }^{4}$ due to SASSA changing the rules for the tender at the last minute, but suspended

\footnotetext{
SASSA 'A statistical summary of social grants in South Africa' Fact sheet: Issue no 8 of 2017.

2 MP Olivier \& E Kalula 'Scope of coverage' in MP Olivier et al (eds) Social security: A legal analysis (2003) 127.

3 Black Sash Trust v Minister of Social Development and others (Freedom under Law NPC as Intervening Party and Corruption Watch (NPC) RF and another as amici curiae) 2017 (5) BCLR 543 (CC) para 1.

4 In terms of section 217 read with sections 33 and 195, of the Constitution of the Republic of South Africa, 1996.
} 


\section{SOUTH AFRICA}

the declaration of invalidity pending determination of a just and equitable remedy. ${ }^{5}$ In the subsequent judgment the Constitutional Court ordered SASSA to initiate a new tender process. It also held that if a new tender is not awarded, the invalidity of the contract with CPS would be suspended until the five-year period for which the contract was awarded, ran its course in 2017. The court required SASSA to report on whether and when it would be ready to start taking over the payment process itself. ${ }^{6}$ In November 2015, SASSA informed the Constitutional Court that it would not be awarding the tender and that it was on track to start paying the grants itself from 31 March 2017.

In 2016 media reports emerged expressing fears that SASSA would not be able to meet the 31 March 2017 deadline to take over the payments of grants. These fears were not unfounded. It turns out that SASSA was aware as early as April 2016 that it would not be able to finalise preparations for taking over the grants in time to meet its overconfident undertaking to the Constitutional Court. The Minister of Social Development also knew from October 2016 that SASSA would not be able to pay grants itself by end of March 2017. ${ }^{7}$ Neither SASSA nor the Minister took any steps to notify the court of the looming national crisis. ${ }^{8}$ By early 2017 SASSA had not taken any steps to conclude a new contract with CPS and was clearly not in the position to start taking over payment of the grants itself.

The Black Sash, a human rights organisation that campaigns for the realisation of socioeconomic rights, particularly the right of access to social security for the most vulnerable people in South Africa, approached the Constitutional Court for an order directing SASSA and CPS to conclude an interim contract for payment of social grants from 1 April 2017 onwards in order to protect access to social assistance to beneficiaries of the grants. To avert the 'potential catastrophe' of grants not being paid, ${ }^{9}$ the court ordered that the constitutional invalidity of the contract between SASSA and CPS is suspended yet again

5 AllPay Consolidated Investment Holdings (Pty) Ltd and others v Chief Executive Officer of the South African Social Security Agency and others (Corruption Watch and another as amici curiae) 2014 (1) BCLR 1 (CC) para 98.

6 AllPay Consolidated Investment Holdings (Pty) Ltd and others v Chief Executive Officer of the South African Social Security Agency and others (Corruption Watch and another as amici curiae) (No 2) 2014 (6) BCLR 641 (CC) para 78.

7 Black Sash Trust v Minister of Social Development and others (Freedom under Law NPC as Intervening Party and Corruption Watch (NPC) RF and another as amici curiae) 2017 (5) BCLR 543 (CC) para 6.

8 See Black Sash, paras 36 and 51.

9 Black Sash, para 15. 
for another 12 months. The Minister and SASSA were also ordered to report to the court every three months on the steps taken to ensure that payment of all grants will be possible after the twelve-month extension. ${ }^{10}$ Notably, the court held that the Minister is 'ultimately responsible' for the crisis and the events that led up to it. She was ordered to show cause why she should not be personally liable for the costs of the application.

Recently, with just six months to go before the latest deadline, SASSA admitted in its report to the Constitutional Court that it is already lagging one month behind schedule in finalising the procurement process, as there have been delays in finding a replacement for CPS. ${ }^{11}$ Once again, concerns have been raised that satisfactory arrangements for the payment of grants may once again not be in place in time to ensure that millions of grant beneficiaries are not left destitute.

\section{CONCLUSION}

The Constitutional Court acknowledged in the Black Sash judgment that separation of powers entails that its power to provide just and equitable constitutional remedies is not limitless and that the exercise of its power in this case 'pushes at its limits..12 However, it regarded the circumstances of the case sufficiently extraordinary ${ }^{13}$ to warrant imposing constitutional obligations on CPS and SASSA that they did not in advance agree to. The fact that the Constitutional Court even considered holding the Minister liable in her personal capacity for the social grants debacle shows how seriously the court takes the threat to access to social assistance 'that for many, especially children, the elderly and the indigent, provides the bare bones of a life of dignity, equality and freedom ${ }^{\prime 14}$

What can be learnt from the series of cases discussed above? Civil society is clearly more than prepared to take up the fight for the social security rights of the most vulnerable people in South Africa. The Constitutional Court, in a series of increasingly scathing judgments, demonstrated that it is prepared to exercise its power to provide constitutional remedies when access to social assistance is threatened, even if it means the suspension of the invalidity of a contract that the court found to be constitutionally invalid. The value of a justiciable right of access to social security has been proven repeatedly as the national grants crisis unfolded. However, it remains to be seen whether SASSA and the Minister of Social Development will be galvanised into taking the necessary steps to ensure that SASSA can meet the 31 March 2018 deadline for finalising arrangements for the payment of social grants. Millions of South African grant beneficiaries are hoping that the Constitutional Court and the country as a whole will not once again be 'confronted with a situation where the executive arm of government admits that it is not able to fulfil its constitutional and statutory

10 Black Sash, para 76.

11 'Six months to go and one month late, in new social grants process shambles' Mail \& Guardian, 15 September 2017.

12 Black Sash, para 51. See also AllPay (2), para 42.

13 Para 8.

14 Para 36. 


\section{SOUTH AFRICA}

obligations to provide for the social assistance of its people.'15 They are pinning their hopes on the supervisory role the Constitutional Court is playing and on the quarterly reports on progress by SASSA and the Minister that the court requires - at least this way there will be advanced warning if South Africa is facing yet another grant payment 'catastrophe'.

15 Black Sash, para 8. 